\title{
Towards an Ethics of Reading Muslims: Encountering Difference in Kamila Shamsie's Home Fire
}

\begin{tabular}{|r|l|}
\hline Journal: & Textual Practice \\
\hline Manuscript ID & RTPR-2018-0082.R2 \\
\hline Manuscript Type: & Original Article \\
\hline Keywords: & $\begin{array}{l}\text { Kamila Shamsie, }<\text { i>Home Fire }</ \text { i }>\text {, British Muslims, ethical reading, } \\
\text { differentiated solidarity }\end{array}$ \\
\hline \multicolumn{2}{|l}{} \\
\end{tabular}

\section{SCHOLARONE \\ Manuscripts}




\begin{abstract}
:
This article explores the ethics of reading across difference in a secular literary marketplace that is increasingly invested in representations by and of Muslims. Focusing on Kamila Shamsie's Home Fire (2017), it considers how this high-profile novel anticipates and negotiates the pressures of anthropological reading practices, especially in its representation of the 'veiled' Muslim woman who can easily become a canvas for the projection of a liberal secular reader's 'enlightened' self. Drawing on Sara Ahmed's work on 'strange encounters' to read the characters' encounters within the novel, the article highlights the novel's concern with the sensory everyday - especially the aural - as a possible means of bypassing the violence of surveillance and the visual more broadly in connecting with others. By examining these encounters, the article considers how the novel negotiates its implied reader's encounter with the text. It argues that while the success of Home Fire lies partly in its use of spectacular, even stereotypical images of Muslims, its overt theatricality in fact opens up a space beyond the frame within which Muslims are normatively seen or read, and enables a reading encounter that resists a transparent translation or easy consumption of difference. Through its analysis of Shamsie's novel, the article explores the possibility of building through reading what Iris Marion Young calls a 'differentiated solidarity’ through reading - a means of forging connections across lines of difference (class and religiosity in particular) without compromising the 'distinction' of that difference - thereby intervening in debates about the ethics of writing and reading others.
\end{abstract}

Keywords:

Kamila Shamsie, Home Fire, British Muslims, performance, ethical reading, differentiated solidarity 


\section{Towards an Ethics of Reading Muslims:}

\section{Encountering Difference in Kamila Shamsie's Home Fire}

\section{Introduction}

In her study of residential segregation and regional democracy, Iris Marion Young argues for the importance of a 'differentiated solidarity', one that recognises and supports difference while also enabling productive communication and, potentially, political mobilisation across lines of difference. Young recognises the benefits of group clustering, especially for minority ethnic groups inhabiting western locations who can be supported and sustained by living together:
The social and political ideal of differentiated solidarity holds that segregation is wrong, but that social group distinction is not wrong. The ideal affirms a freedom to cluster, both in urban space and in religious, cultural, and other affinity group associations. This freedom should be balanced with a commitment to non-discrimination; spatial and social clustering, that is, cannot be based on acts of exclusion, but rather on affinity attraction. ${ }^{1}$

This balancing of the significance of the communal with the need to work against spatial structures of exclusion to facilitate communication across difference is crucial for recognising, and moving towards equality for, minority ethnic identities in multicultural British society. It works against the liberal tendency to relegate cultural difference to the private sphere and stigmatise minority subjects who choose to maintain their cultural practices within (and aided by) defined, but porous, boundaries. The idea of a differentiated solidarity is particularly important when considering Muslims in Britain, because of the distinction of Muslim cultural practices from majoritarian British culture, which marks their difference visibly, and because of their tendency to cluster physically which can be traced to 
social deprivation and 'white flight', as well as to a commitment to the preservation of certain modes of living. ${ }^{2}$ This has led to the levelling at Muslims of highly problematic accusations of 'self-segregation'. ${ }^{3}$ As well as working against such accusations, Young's concept retains an emphasis on the importance of forging links across the boundaries of community, which is central to a successful multiculturalism of reciprocity.

In this article, I draw on Young's theory to consider how we read across cultural and religious, as well as social and racial, difference. Specifically, Young's theory helps me think through how we might read across difference more ethically, and whether and how Kamila Shamsie's 2017 novel Home Fire facilitates an ethical reading of the British Muslim lives it depicts in the context of a literary marketplace which is increasingly invested in fictional representations of Britain's cultural diversity, ${ }^{4}$ and in which writing by and about Muslims has become a notable presence over the last decade. ${ }^{5}$ In this context, the importance of mediating Muslim identities and cultures to a heterogeneous but predominantly secular readership is in tension with the risk of facilitating an exoticising consumption of that difference, one which translates or dilutes difference into something that can be understood within, or assimilated to, normative (read: liberal and secular) paradigms. ${ }^{6}$ Here, I build on the work of Sarah Brouillette, Graham Huggan and Madhu Krishnan, which, in different ways, explores the way postcolonial writers mediate cultures and locations of the global South for an Anglo-American readership. Informed by this work, my article considers how Shamsie, an increasingly high-profile writer of Muslim heritage, negotiates the role of gatekeeper to 'her' community of difference for a diverse but predominantly white, middle-class and secular British readership in her most recent prizewinning novel. ${ }^{7}$ Shamsie is one of a handful of acclaimed 'Muslim' writers who combine their literary craft with journalistic writing for the British press, which positions them as public intellectuals and perhaps, uncomfortably, as 'native informants' ${ }^{8}$ Moreover, with 
Home Fire, Shamsie's fiction enters Britain and the realm of post-9/11 multicultural British politics and terror for the first time. Hence, the novel is particularly susceptible to anthropologically inflected readings that seek the 'truth' about British Muslims and radicalisation.

My focus is not on readers themselves, but rather on tracing the text's awareness of and anxieties about how it will be read, ${ }^{9}$ given its inevitable position as a 'literary mediator' of difference ${ }^{10}$ in a fraught context where Muslim 'others' are frequently the objects either of exclusionary and stigmatising discourses and practices, or of a well-intentioned curiosity that can tip into a fetishisation of difference. With reference to fictional representations of Africa, Krishnan writes that 'the aesthetic function of the literary text is always implicitly positioned alongside a parallel and pre-existing sociopolitical discourse of representation'. ${ }^{11}$ Shamsie, too, contends with the difficulty of writing Muslims 'under the spectre of the already-known', an image, or set of images, which hardly need rehearsing, and which can serve as a canvas for the projection of the spectator's enlightened secular self. ${ }^{12}$ In line with Bethan Benwell, James Procter and Gemma Robinson's call for the importance of developing an ethics of reading, ${ }^{13}$ my concern is to explore how the novel negotiates conflicting pressures in its attempt to facilitate an ethical reading, one which disturbs 'dichotomous divisions' between reader and subject, 'saviour' and 'victim', or 'self and other'. ${ }^{14}$ Young's notion of differentiated solidarity helps illuminate and more sharply define an ethical reading as one that disables an easy consumption of cultural difference, while nevertheless retaining the possibility of communicating that difference to the reader effectively, in order to create the potential for some form of solidarity across difference. In other words, reading across difference in an ethical and politically resistant manner entails both a recognition and affirmation of the 'distinction' of difference (that it resists translation into transparency and defies an 'anthropological' mode of reading) and an openness to 
connecting with that difference and readiness 'to be changed by what it has to offer'. ${ }^{15} \mathrm{My}$ reading of Home Fire, then, will focus on the encounters that take place between the central characters to consider how the novel negotiates its implied reader's encounter with the text. Framed by Sara Ahmed's work on ethical modes of encountering others, it asks, crucially, whether and how the novel interpellates its reader in a way that 'resist[s] thematising [Muslim] others as "the other", ${ }^{16}$ while nevertheless forging connections across difference, thereby building a differentiated solidarity through reading.

\section{Surveillance and performance}

In this section of the article, I consider Home Fire's exploration of ways of surveilling or reading Muslims. This exploration, I argue, reveals its own self-consciousness about how its depiction of Muslims might be read. By scrutinising modes of viewing others, the novel directs the reader's attention towards their own readerly gaze, encouraging a more selfconscious way of reading. Further, by departing increasingly from realist conventions towards a more spectacular, theatrical style, the novel distances its reader from its Muslim subjects and deflects an anthropological mode of reading which can limit western, nonMuslim responses to fictional representations of Muslims. In these ways, the novel helps us think through what might constitute a more ethical mode of reading across difference.

Home Fire takes surveillance as one of its key concerns. Most obviously, it is concerned with the impact of MI5's surveillance of siblings Isma, Aneeka and Parvaiz Pasha, first because of their father's radicalisation and consequent detention at Bagram before his death in transit to Guantánamo Bay, and later because of Parvaiz's own recruitment to the 'media wing' of Islamic State in Syria. ${ }^{17}$ Yet, beyond this, the novel incorporates the monitoring by and of Muslim Conservative MP Karamat Lone in London, as well as Isma's subjection to 
interrogation before boarding her flight to the US (3-7), the siblings' monitoring of each other's movements on Skype (30-31), the media's surveillance of Aneeka after Parvaiz's death (188-92, 197-8, 201, 204, 206-7), and Karamat's privileged son Eamonn's scrutiny of his lover Aneeka, who seduces Eamonn in order to gain influence with his powerful father in the hope that he will help bring home her beloved twin Parvaiz. It is with the latter, which operates partly through the trope of the veil, that the interplay of surveillance and subterfuge is most compellingly explored, in ways which cast light on the politics of writing and reading Muslims.

In her seminal reading of the western fascination with veiling practices in the Muslim world, Meyda Yeğenoğlou explores how the elusive nature of the veiled Muslim woman incites in the (white, colonial) man a desire to transform her difference into 'a manipulable and enjoyable object of discourse' in order to provide himself with 'a sense of the fictive unity and command of his experience'. ${ }^{18}$ For Yeğenoğlou it is precisely the assumed unknowability of the veiled woman that threatens the viewer's command of knowledge and elicits their need to decipher her. In the contemporary British context, this drive to read visible markers of Muslim difference - and assumed inscrutability - as transparent symbols is evident in the frequent 'decoding' of the 'veil' or beard as signifying specific characteristics, whether patriarchal religious oppression, cultural separatism, radicalism, or a combination of these. This need to impose a singular reading on Muslims, then, reveals the anxiety of the viewer or reader when confronted by religious difference. Hence, the inscrutability attributed to the Muslim subject can be reconfigured as a projection of the observer's own incomplete vision, destabilising the authority of their surveillance or reading practices. Reconfiguring the encounter in this way enables the Muslim subject to withhold the distinction of their difference from scrutiny, labelling and consumption. 
In Eamonn's narrative, the second of five parts or 'acts' in this contemporary reworking of Sophocles' Antigone, Aneeka's presence dominates, with her hijab frequently forming the focus. Despite Eamonn's part-Muslim heritage (he is of Pakistani and white Irish American descent), his gaze is clearly exoticising, at times reducing Aneeka to the double-sided Orientalist stereotype of the veiled Muslim woman as chaste yet lascivious, inaccessible yet promiscuous, mysterious yet the ultimate object of knowledge. ${ }^{19}$ In a series of images, her religiosity, emblematised by her hijab, overlays her sexualised body. When Eamonn meets her, his first thought is 'how he might use [his greasy fingers] to unpin the white hijab that framed her face' (64). Back at his Notting Hill apartment, he observes her unpinning her hijab to let down her long, dark hair, 'like something out of a shampoo advertisement' (68); while shortly afterwards, the image of her at prayer, with a 'scarf loosely covering her head', is spliced with one of her 'down on her knees for a very different purpose' (70). This sequence builds to a crescendo as Aneeka offers herself to Eamonn naked but for 'the white scarf covering her head, one end of the soft fabric falling just below her breast, the other thrown over her shoulder', purposefully playing to his fantasies (71). While Aneeka literally unravels her hijab to make herself sexually available to Eamonn, the mystery of her is not unravelled, and she remains 'unreadable' or inscrutable to him ( 84 ; see also $77,85,74)$. Of course, the reader knows that Aneeka is purposefully withholding knowledge about herself and her motivations from Eamonn. The fact that her apparent elusiveness is in reality an intentional act partly dismantles the stereotype of the inscrutable Muslim woman with which Eamonn fixes her. Eamonn, moreover, is constructed as naïve and disempowered. If the supposed unknowability of the veiled Muslim woman incites in the observing privileged, secular man a seductive desire to fix her difference, or transform it into a knowable object, to attain 'a sense of the fictive unity and command of his experience', then, in the case of Eamonn, this process of transformation, objectification and command is thwarted. ${ }^{20}$ Indeed, 
Aneeka performs for Eamonn, constructing a persona for his fantasies but for her interests, and it is she, therefore, who assumes the position of command, subverting the relationship of power that connects them. While the reader is privy to Eamonn's curiosity about Aneeka and his attempts to 'read' her, it is arguably Aneeka who is the more confident reader of Eamonn. Aneeka's material veil, then, symbolises her ability to 'look without being seen' and to 'turn [herself] into a surveillant gaze'. ${ }^{21}$ As Yeğenoğlou points out, '[i]t is in this space of absent-presence that there emerges the challenges of the "invisible", "hidden" other'. In other words, it is here that the possibility of resistance can be located. Further, this resistance, as well as thwarting the western, secular subject's knowledge, also works to 'destabilize the identificatory process of the subject' himself, ${ }^{22}$ or to disturb his sense of a coherent self. Just as Yeğenoğlou refocuses the spotlight from the object of western fantasies to the observing subject, so the novel scrutinises Eamonn (scrutinising Aneeka). What is under surveillance here, then, is not practices of veiling, or Islam more broadly, but what Peter Morey and Amina Yaqin describe as 'the locus of misrecognition', ${ }^{23}$ the viewer whose vision is flawed and whose self is split.

As well as resisting Eamonn's knowledge, Aneeka remains elusive to the reader. Notably, Aneeka's own narrative strand is packed with other voices, especially voices from the media. Of the nineteen short fragments that make up the narrative, four are extracts from different kinds of newspaper report, two are snapshots from Twitter threads, one is composed entirely of speech, and another is a short poem. The media voices are reductive and pernicious to varying degrees, distorting the histories and realities of the lives of the Pasha family, and violating their privacy, with the headline of the final, tabloid-style article declaring 'Hojabi! Pervy Pasha's Twin Sister Engineered Sex Trysts with Home Secretary's Son' (204). Given the novel's roots in Sophocles' Antigone, these voices could be understood as performing the role of the Chorus in a Greek tragedy, guiding the audience to 
a certain reading of events. Yet, their clear distortion instead places the onus on the reader to read individually and critically, beyond media soundbites and stereotypes. Where we do gain access to Aneeka's voice, at times this is in note form: the narrative feels rushed, frequently omitting the subject ('she'), as if it is reflecting the erosion of her selfhood that she experiences on learning of her twin brother's death, or her single-minded resolve to bring his body home, or perhaps her own limited voice as a working-class visibly Muslim woman. Yet, an effect of this is to distance the reader. While in the final section of the novel, told from Karamat's perspective, Aneeka is also a focal point, here, too, she is distanced both from Karamat and from the reader. In an attempt to bring her dead brother back to Britain, Aneeka engages in a highly stylised form of consecration and preservation of his body. Equipped with an ice coffin, rose petals, and a white sheet, her self-conscious performance is doubly mediated - first by the cameras that are filming her in Islamabad, and second by Karamat's interpretation of the images he watches on television, with the sound significantly muted. The layers of mediation serve to keep the reader at bay, along with Karamat and members of the viewing public, eager for corroboration of what they 'know' about Muslim women. While we can see beyond the name-calling of the tabloids - 'Slag, terrorist-spawn, enemy-of-Britain' (229) - we are left with an elusive subject. In this sense, the 'surveillant gaze' on her is subverted, or at least undermined; she is doubly, or perhaps triply, veiled.

The failure, or partiality, of readerly identification with Aneeka is all the more striking when contrasted with the novel's opening section which is focalised through Isma. Here, the use of free indirect discourse to render, in realist mode, Isma's experience of travelling to Massachusetts, navigating life there, and falling in love, in the wake of her brother's departure for Syria, enables an emotional transaction between the reader and a young observant Muslim woman. Thereafter, this transaction is increasingly denied the reader, as 
Isma recedes from the narrative and Aneeka, rendered at a distance, through layers of mediation, assumes centre stage, culminating in the self-conscious theatricality of her presence in the novel's final 'act' which inclines towards melodrama. Indeed, Peter Ho, in his review of the novel, comments on the 'stagy' quality of its final 'act', and the 'distancing effect' of this 'stylistic shift' to self-conscious theatricality. ${ }^{24}$ While this distancing of Aneeka might lend itself to the neo-Orientalist construction of the Muslim woman as inscrutable, arguably the layers of mediation disable consumption of her difference by readers both within and of the text. In this sense, the narrative can be understood as resistant to the demands of the western secular reader to 'know' the Muslim woman. The proliferation of both fiction and memoirs by writers of Muslim heritage in the decade following 9/11 points to a readership eager for such 'knowledge', which in turn exerts pressure on Muslim writers to produce 'authentically' representative fictions. ${ }^{25}$ In an article on Leila Aboulela's 2005 novel Minaret, Peter Morey comments on the 'unvarnished realism' of this practising Muslim writer's work, which, he argues, 'attempts to conciliate what might be called "anthropological" readings of Muslim writing, which see texts by an avowedly religious subject as offering insights into the mind of the "other"' ${ }^{26}$ Aboulela is certainly not the only writer whose work has been read in this way. ${ }^{27}$ Shamsie's novel, I argue, problematises this mode of reading. It is precisely through its theatricality that the novel eschews the anthropological, deflecting readings which interpret fictional Muslim characters and communities as representative of their culture or faith. By foregrounding the layers of mediation through which we observe the other, the narrative withholds an 'authentic' Muslim subject, placing in metaphorical scare quotes the at times familiar, even hackneyed images it offers us, as well as encouraging us to reflect on our own reading practices. 
In Framing Muslims, Morey and Yaqin discuss the notion of 'parodic performance' or 'hyperperformativity', ${ }^{28}$ applying it to the work of Pakistani British comedian Shazia Mirza in particular. While the theatricality that emerges increasingly in Shamsie's novel is not 'parodic', the idea of hyperperformance is helpful in illuminating the politically subversive potential of the novel's melodramatic 'staginess', especially in its representation of Aneeka. Reading Mirza through the work of Judith Butler, Morey and Yaqin maintain that just as the performance or masquerade of femaleness "can be "troubled" by its "subversive repetition" and "parodic recontextualisation"”, so Mirza's post-9/11 hyperperformance of a hijab-clad Muslim woman 'operated as masquerade - raising questions about whether "Muslimness" could be finally identified and pinned down or in fact was always being confused with its outward signifiers'. ${ }^{29}$ In other words, it pointed to the gap between image and an undefineable reality. They go on to assert that 'Mirza was encoding the cultural identity of Muslimness as it was perceived by the viewer: in other words, she was subverting a stereotype by employing, repeating, and exaggerating it' - thereby 'calling into question any idea of an "original" truth behind the image' ${ }^{30}$ Not only does such hyperperformativity debunk the very notion of authenticity, then, it also refocuses the spotlight on the viewer, or in this case the reader, as the 'locus of misrecognition', rather than on 'Muslimness' itself. ${ }^{31}$ Just as it is Eamonn's 'misrecognition' or failed reading of Aneeka that forms the focus of his narrative strand while Aneeka herself remains largely unknowable, concealed beneath her performance, so it is our own observation or (mis)reading that is placed within the frame of the novel's final section. It is in this sense that the novel can be seen to reference but avoid repeating the stereotype of the inscrutable veiled Muslim woman.

Tahmima Anam hints at a subversion of an anthropologically inclined reading of the novel when she writes of Home Fire: 'it managed to ... give me a tiny glimpse into the otherness of others' ${ }^{32}$ In other words, this subversion works to 'protect or preserve the otherness of 
the other' by deflecting or resisting commodification or consumption. ${ }^{33}$ When a representative from the Pakistan High Commission in London visits the Pasha family to inform them of Parvaiz's death, Aneeka, in a state of denial and shock, tells him: 'He wasn't one of yours ... we aren't yours' (184). The meaning of these words becomes clearer in a subsequent exchange with the official in which she refutes the Pakistani identity ascribed to them and lays claim to British citizenship. But the fact that they first appear decontextualized and open to interpretation suggests a more general refusal to be fixed by definitions and labels imposed by others (whether 'terrorist' or 'jihadi', 'niqabi' or 'hijabi'), and an assertion of their autonomy and right to self-definition within Britain. Further, the last three words - 'we aren't yours' - might also be read as an address to the reader, a refusal to be translated for easy consumption by the white, secular, middle-class reader in particular. Here, we might return to the adaptation of Young's notion of a differentiated solidarity, which I outline above. If - extrapolating from Young's contention that 'social group distinction', ${ }^{34}$ or more broadly the retention of cultural difference, positively enables minority subjects - reading difference ethically entails a recognition of the 'distinction' of difference, then arguably Shamsie's novel facilitates such a reading practice by retaining the opacity of that difference and thereby obstructing its anthropological consumption.

\section{Ethical encounters}

This section reads further encounters in the novel as a way to think some more about readers' encounters with the text and the novel's own anxieties about and negotiation of the ethics of reading across difference. Coupled with Home Fire's emphasis on performance and the spectacular as a means of deflecting anthropological reading practices, is an exploration of how we might read others more ethically by engaging our other senses. 
Drawing on Sara Ahmed's work on 'strange encounters', I highlight the novel's concern with the sensory everyday - especially the aural - as a possible means of bypassing the violence of surveillance and the visual more broadly in connecting with others. While moments of real connection between the novel's protagonists are rare and fleeting, I argue that Home Fire's deflection of anthropological, appropriative readings creates a productive unease for readers, which, combined with the novel's decentred intra-Muslim perspective, moves some way towards breaking down a 'them and us' dichotomy between secular western readers and the text's Muslim subjects, facilitating a more ethical mode of reading. The novel's emphasis on performance and surveillance highlights the role of the visual in shaping or entrenching perceptions of others, and thereby entrenching barriers between cultural groups, or impeding communication across them. It is the visibility of their difference in the public sphere - whether this takes the form of veiling or prayer in schools or courts of law, or a community whose infrastructure is dominated by services that cater for its religious culture - that makes British Muslims especially susceptible to racism. ${ }^{35}$ Morey and Yaqin describe how British Muslims 'find themselves in ... a double bind of performativity' as they are called upon to perform both their 'Britishness' and their 'Muslimness' in the public sphere. ${ }^{36}$ Notwithstanding his class privilege, Karamat Lone's public role places increased pressure on him to perform 'Britishness' or the 'good Muslim' for the public eye. For example, caught entering a mosque associated with a 'hate preacher', he responds by publicly walking into a church with his wife in order to assert his 'Britishness' (35), thereby winning votes from his white constituents while alienating Muslims. Eamonn echoes his father's cultural and spatial navigation when on his way to Aunty Naseem's: he crosses a road to avoid walking past a mosque, then crosses back 'so as not to be seen as trying to avoid a mosque' (59). Of course, it is not visible cultural difference itself that cause divisions - as Karamat would have it (87) - but rather the 
surveillant gaze that fixes the religious 'other', consigning them to a particular, boundaried place. As Sara Ahmed writes, the recognition of others 'operates as a visual economy: it involves ways of seeing the difference between familiar and strange others as they are (re)presented to the subject. As a mode of subject constitution, recognition involves differentiating between others on the basis of how they "appear". 37

In the light of this, we might read Parvaiz's preoccupation with sound as signalling to the reader the potential, or at least the need, for a means of communicating across difference that bypasses the distorting properties of the image and the violence of surveillance. While Karamat turns the sound off when viewing images of Aneeka mourning her brother, Parvaiz privileges sound over vision in his reading of the world. Indeed, in the soundscape that he creates from the roof of his garden shed, a 1,440 track 'of every minute of a day ... recorded over 1,440 days', the only fragments of speech are every-day, almost banal comments belonging to Aneeka (131). ${ }^{38}$ This points to the limits of language, too: the labels 'terrorist' and 'jihadi' immediately conjure images which fail to capture the complex reality of Parvaiz; while the seductive power of the decontextualized, fragmented images of Adil Pasha helps to misdirect his son towards a future he does not want. Yet, for the aural to circumvent the travesties of the visual, hearing must entail listening. ${ }^{39}$ While working as a sound engineer for IS, Parvaiz is at first partly successful in his attempt to abstract the sounds he hears with such precision from their horrific meaning (170), which only becomes insufferably clear once he begins to listen. If seeing lures Parvaiz into IS, listening makes him leave $(145-59,174)$. Aneeka, too, with the repeated phrase of 'Hear that', teaches Eamonn how to 'listen to the sounds of the world': she encourages him to record the time he spends without her, to bring her the 'soundscape of [his] days' (89). In this respect, the novel's injunction is, broadly, to listen closely, to interpret what we hear with care, 
especially when the cultural other is speaking, in order to move through the reductive signs and symbols that seduce or repel, or do both together.

Indeed, it is not insignificant that it is the aural that takes Karamat into a borderline space when Isma visits him in his home. When Isma accidentally activates the ice-cube dispenser on Karamat's fridge, its noiselessness recalls for him 'the rattling, groaning ice dispenser in the fridge door of one of the Wembley relatives' of his childhood (235), taking him into an uncanny space of familiar difference. For the discomfort Karamat feels in Isma's presence is not primarily because of the social chasm between them, but rather because of her familiarity. When she looks at him, 'something passed between them - it wasn't about sex, but something that felt more dangerous. She was familiar to him, a reminder of a world he's lost' (238). The aural reminder of the ice cubes disrupts the visual by forcing Karamat to connect with Isma as someone familiar, beyond the image of a 'hijabi' or an object of desire. It takes Karamat into a space of productive dissonance or discomfort - one that has the potential to enable an encounter across lines of difference, or beyond the frame. The ice cubes recall two earlier scenes in the novel. The first is the curious sound of ice falling on icicles outside Hira Shah's Amherst apartment which enables Isma to recall her brother lovingly, beyond the image of the IS recruit that she has had to reduce him to (12); the second is Adil Pasha dipping his head into a Chechnyan mountain stream to perform his ablutions and emerging with a beard full of icicles which 'produced the sound of wind chimes', and evokes, for Parvaiz, 'the father he'd never known' (128). In both cases, the sound of ice serves as a kind of fracture in the visual, a means of getting beyond a static image (of 'terrorist' or 'hijabi'), and thereby forging a connection with an other. The novel's focus on sound recalls Sara Ahmed's exploration of hearing in encounters across difference. For Ahmed, '[t]o hear, or to give the other a hearing, is to be moved by the other, such that one ceases to inhabit the same place'. ${ }^{40}$ In other words, it is hearing, or listening, that 
facilitates movement beyond one's own place, to a space or discomfort, where one is out of place. Further, it is precisely by acknowledging the necessity of gaps in communication, or the importance of 'that which fails to get across', that an ethical encounter can take place. Or, put differently, it is through retaining an element of distance from the other that closeness can be facilitated. Ahmed continues:

What allows us to face each other ... is also what allows us to move beyond the face, to hear and be touched by what we cannot grasp, as that which cannot be assimilated in a moment of recognition of either 'the Other' or the stranger. (158)

Hence, in encounters across difference, she encourages us to move beyond what we can see - the images that can work to fix people into stereotypes - to engage our other senses, touch as well as hearing, in order to avoid the trap of assimilating or translating difference into the familiar. By doing so, we might open ourselves up to the 'distinction' of that difference, in line with Young's notion of a 'differentiated solidarity'. In the case of an encounter between a niqab-clad Muslim woman and her secular white interlocutor, then, Ahmed's thinking might encourage the latter not to ask to see her face, but to look beyond the fact that it is covered, perhaps by listening. ${ }^{41}$ To apply Young's theory, a connection - towards solidarity - is made by respecting her difference, not by attempting to diminish or appropriate it.

The sounds captured in Parvaiz's recordings and in the recordings Eamonn makes for Aneeka, as well as the ice cubes that take Karamat back to his childhood, point to the significance in the novel of the everyday as a potential means of forging connection across difference. Indeed, as in these examples, it is often the sensory everyday that enables connections. So, for example, in one of their early meetings in an Amherst cafe, Eamonn asks Isma to find a Pakistani pop song that takes him back to the Wembley interludes in his privileged childhood, before the two share a plate of food, a sign of their 'intimacy' or 'comfort' with one another, captured in one of the few Urdu expressions Eamonn knows, 
'bay-takalufi' (28-9). The idea of food as an everyday vehicle for transgressing social and cultural boundaries recurs when Eamonn visits Aunty Naseem's house and is served samosas which he thanks her for with the Urdu word 'Shukriya', an incident in which sound and taste again combine to displace him into a distant part of his childhood (62); when Eamonn and Aneeka pit and eat cherries together in Eamonn's rooftop garden in a scene marked by touch and sensuality (92-3); and when, on the cusp of the fracturing of their family, Aneeka cooks dinner, aided by Parvaiz, to the sounds of South Asian music, the hum of the refrigerator, a train pulling out (117). If the emphasis on hearing primarily, but also taste and touch, suggests the potential for bypassing the divisive effects of the visual, the focus on the everyday is redolent of Paul Gilroy's notion of conviviality, the 'emancipatory interruptions' that can occur in contemporary British multiculture and that are defined precisely by their banality and ordinariness. ${ }^{42}$ Indeed, the everyday is also a vehicle for subverting and disrupting boundaries for Michel de Certeau. In his conceptualisation of urban space and the way we navigate it, de Certeau underlines the role of the visual in imperialistic practices of mapping, which contrasts with the necessary blindness of subversive practices that can cut across cartographic borders. ${ }^{43}$ For de Certeau, the 'ordinary practitioners of the city' live 'below the thresholds at which visibility begins ... These practitioners make use of spaces that cannot be seen; their knowledge of them is as blind as that of lovers in each other's arms'. ${ }^{44}$ We might consider Aneeka and Eamonn's encounters, as well as other characters' encounters which take them fleetingly into uncanny spaces of productive dissonance, in these terms; ${ }^{45}$ and we might read the novel's interest in the sensory everyday as a means of exploring the possibilities for communicating across material lines of difference and beyond the visual - possibilities that do not, however, become realities. 
With its focus on failed encounters, then, the novel seems to suggest the difficulty of moving beyond the frames which constrain British Muslims, at least in the present. Yet by drawing attention to the surveillant pressures operating on Muslims, both through its rendering of encounters between characters, and through its increasing artifice, or theatricality, which turns the spotlight on the reader's encounter with the characters, Home Fire opens up a space for reflection, beyond the stereotypes that it deploys. It could even be said that by withholding an authentic 'Muslimness' and refocusing the spotlight on the reader, the text pulls the latter into its frame, thereby breaking down the self/other dichotomy between reader and characters, and enabling some connection across difference. In this sense, the reader is made to occupy an uncomfortable position within the text, the productively uncanny space that Karamat momentarily occupies in his encounter with Isma. In her reading of literary representations of Africa, Krishnan emphasises the importance of 'an understanding of non-understanding', a suspension of the need to 'understand' difference, as a way of carving out a 'space within which to form an ethical existence' or an ethical reading position. In Home Fire, the 'mode of encounter', of reader and text, does not 'hold the other in place, or ... turn her into a theme, concept or thing'. ${ }^{46}$ Rather, the reader is 'made to feel not at home with the text or in [them]selves', ${ }^{47}$ and it is this unhomeliness wherein lies the possibility for moving towards a partial fracturing of exclusionary notions of 'them' and 'us' which define who can and who cannot feel at home in Britain.

Within Home Fire, all of the significant encounters are between British Muslims, rather than between Muslims and white secular Britons. The novel's concern with British Muslims' failed communication with one another shifts the focus partly from cultural and religious difference to class difference - for while the characters are divided also by the extent of their religiosity, arguably this is shaped primarily by class $(18,91)$. An effect of the novel's all-Muslim cast is to underline the heterogeneity of British Muslims, and so break down the 
dichotomy between non-Muslims and Muslims. A further effect is, arguably, to break down the division between Muslim object of reading and secular reading subject. Drawn into a network of different Muslim characters who are often 'reading' or misreading each other, the reader is denied an extended relationship of empathy with a single dominant narrator or focalising character - which in turn minimises what Krishnan, citing Marcus Wood, describes as the danger of "fall[ing] into self-interested "appropriative empathy", ${ }^{48}$ of developing an affective connection with a character that in fact fetishizes or appropriates their difference and reduces them to the 'already-known', ${ }^{49}$ while 'mask[ing]', or at least attenuating, 'the inequality of the power relations' that structure the world we share. ${ }^{50}$ In this way, the decentred intra-Muslim perspective facilitates a more ethical mode of reading.

\section{Building a 'differentiated solidarity' through reading}

In his article 'The Postcolonial Everyday', James Procter explores the 'cultural work everyday expressions might perform at a moment when Asian experience seems increasingly bifurcated from English daily life'. ${ }^{51}$ Noting the prevalence in cultural representations of 'extreme, extraordinary versions of South Asian culture in the UK since 9/11', which are, as he puts it, 'split between exoticism and fanaticism, between the fetish for difference and the fear of terrorism', he investigates the ways in which a body of British Asian films presents a productively 'mundane' alternative. ${ }^{52}$ On the surface, Shamsie's novel immerses itself in 'exoticism' and 'fanaticism', the sensationalist images and discourses that characterise cultural representations of British Asians (particularly those of Muslim heritage), even while it draws attention to and arguably undermines such images and discourses, through its focus on the everyday as an avenue for facilitating meaningful communication, as well as its theatricality. The novel's allusion to the phrase 'Keep the 
home-fires burning', the title of a patriotic First World War song, most obviously connotes the exclusionary understanding of Britain as home - one which is underpinned by continuing patriotism or imperialistic nostalgia, and one which is denied to Parvaiz, both living and dead. Yet the title also carries within it the tension between the spectacular images on which the novel trades and its concern with undermining these: while 'home' is, as Procter describes, a 'privileged symbol of the everyday', 53 'fire' evokes the terroristic violence that is the most obvious subject of the novel. While it critiques the surveillant gaze which freezes Muslim subjects, particularly visibly Muslim women and young disenfranchised Muslim men, into stereotypical images, it also inevitably benefits from its investment in these images that can so easily be read to corroborate the 'extreme, extraordinary versions of South Asian [Muslim] culture' that Procter outlines - images that tip into melodrama and sell books in the literary marketplace. In particular, the melodrama of the novel's final scene, in which the lovers are reunited only to face a violent death, might be read as corroborating the corrosive stereotypes that circulate. Hence, the novel treads a dangerous path. Echoing but adapting Morey and Yaqin's interrogation of the use of hyperperformativity in Shazia Mirza's comedy, we might ask how far 'the strategic assimilation and deliberate transgression of [such] stereotypes' takes us beyond them, especially given how susceptible they are to misreading. ${ }^{54}$

Further, while the novel's use of performativity highlights the dangers of the surveillant gaze, the fact that the Pasha siblings are reduced almost to a series of silent masks by the end of the novel - Aneeka most obviously, while Isma fades away, and Parvaiz's corpse is masked in ice - remains troubling. In a sense, their 'Muslimness' is diminished to the point that it becomes barely more than the silent object of the gaze, leaving little space for a positive assertion of visibly cultural difference in the novel, or for the speech that is required to make listening effective and dialogue possible. ${ }^{55}$ Yet, I read this as a consequence of the 
novel's reluctance to speak for a community of difference. For if Eamonn occupies a peripheral position in relation to the Pasha family, Shamsie herself occupies a peripheral position in relation to the characters and community she renders. Indeed, the difficult encounters between the characters, the breakdown in communication which marks them, also points us to the uneasy position occupied by a narrative authored by an elite cosmopolitan Muslim that attempts to translate working-class Muslim lives to a middleclass white secular reader. ${ }^{56}$ As I've argued elsewhere, literary controversies involving minority religious communities in Britain, such as that surrounding Monica Ali's novel Brick Lane, ostensibly about religious offence, can concern ownership, too - or, more specifically, the feeling of being disowned by an elite cultural representation of a community, particularly one that either claims to be or is perceived as representative or even 'authentic'. ${ }^{57}$ While recent debates around cultural appropriation have tended to centre on racial difference (white writers rendering minority ethnic characters), we might legitimately bring class and religiosity into the mix, to explore the ethics of a privileged secular writer depicting the lives of her under-privileged religiously observant counterparts who have less access to representation, or less freedom to speak. ${ }^{58}$ If, as I've argued, Shamsie's novel withholds 'ownership' of the characters from the reader through its increasing theatricality, we might read in this an anxiety or unease about the ethics of writing and reading across lines of difference, about how a writer can avoid taking ownership of, or speaking for, a community from which they are distanced through privilege despite an affiliation. Home Fire navigates this perilous terrain by giving the reader access to a cast of British Muslims, while at the same time denying the reader an appropriative consumption of their 'Muslimness' through an increasingly exaggerated, melodramatic style which disturbs a reading of the characters as 'authentic'. In this way, the novel encourages readers to recognise the distinction of the difference they encounter as well as to reflect on their own 
practices of reading across difference. The reader is displaced in a sense - or denied their usual way of reading a representation of British Muslims - and this displacement is a first step towards being receptive to and therefore communicating effectively across difference, in order to build a differentiated solidarity through reading.

Wordcount: 8365 
${ }^{1}$ Iris Marion Young, Inclusion and Democracy (Oxford: Oxford University Press, 2000), 224.

${ }^{2}$ Rehana Ahmed, Writing British Muslims: Religion, Class and Multiculturalism (Manchester: Manchester University Press, 2015), 4, 32-33.

${ }^{3}$ See Tahir Abbas, 'British South Asian Muslims: Before and After September 11', in Muslim Britain: Communities Under Pressure, ed. Abbas (London and New York: Zed Books, 2005), 3-27, $12,4$.

${ }^{4}$ Claire Squires, 'Too Much Rushdie, Not Enough Romance? The UK Publishing Industry and BME (Black Minority Ethnic) Readership', in Postcolonial Audiences: Readers, Viewers and Reception, ed. Benwell, Procter and Robinson (London and New York: Routledge, 2012), 99-111.

${ }^{5}$ Rehana Ahmed, Peter Morey and Amina Yaqin, 'Introduction', in Culture, Diaspora, and Modernity in Muslim Writing, ed. Ahmed, Morey and Yaqin (London and New York: Routledge, 2012), 1-17, 1-2.

${ }^{6}$ Graham Huggan, The Postcolonial Exotic: Marketing the Margins (London and New York: Routledge, 2001), 13-14, 27.

${ }^{7}$ Home Fire won the 2018 Women's Prize for Fiction.

${ }^{8}$ This is not to suggest that Shamsie's journalism is confined to 'Muslim' matters; in fact, its subject matter is notably wide-ranging.

${ }^{9}$ Sarah Brouillette, Postcolonial Writers in the Global Literary Marketplace (Basingstoke: Palgrave, 2007), 4, 6-7.

${ }^{10}$ Ibid., 39.

${ }^{11}$ Madhu Krishnan, 'Affect, Empathy, and Engagement: Reading African Conflict in the Global Literary Marketplace', The Journal of Commonwealth Literature 52(2) (2017), 212-230, 213.

${ }^{12}$ Ibid., 228.

${ }^{13}$ Bethan Benwell, James Procter and Gemma Robinson, 'Introduction', in Postcolonial Audiences: Readers, Viewers and Reception, ed. Benwell, Procter and Robinson (London and New York: Routledge, 2012), 1-23, 16-18.

${ }^{14}$ Krishnan, 'Affect, Empathy, and Engagement', 220

${ }^{15}$ Derek Attridge, 'Responsible Reading and Cultural Distance', in Postcolonial Audiences:

Readers, Viewers and Reception, ed. Benwell, Procter and Robinson (London and New York: Routledge, 2012), 234-44, 235.

${ }^{16}$ Sara Ahmed, Strange Encounters: Embodied Others in Post-Coloniality (London and New York: Routledge, 2000), 141.

${ }^{17}$ Kamila Shamsie, Home Fire (London: Bloomsbury, 2017). All references to this edition of the novel will be given in the body of the article.

${ }^{18}$ Meyda Yeğenoğlou, Colonial Fantasies: Towards a Feminist Reading of Orientalism (Cambridge: Cambridge University Press, 1998), 47.

${ }^{19}$ See Yeğenoğlou, Colonial Fantasies.

${ }^{20}$ Ibid., 47.

${ }^{21}$ Meyda Yeğenoğlou, 'Veiled Fantasies: Cultural and Sexual Difference in the Discourse of Orientalism', in Feminist Postcolonial Theory: A Reader, ed. Reina Lewis and Sara Mills (London and New York: Routledge, 2003), 542-66, 557.

${ }^{22}$ Ibid., 555-57.

${ }^{23}$ Peter Morey and Amina Yaqin, Framing Muslims: Stereotyping and Representation After 9/11. (Cambridge, Mass.: Harvard University Press, 2011), 196.

${ }^{24}$ Peter Ho, 'An "Antigone" for a Time of Terror', The New York Times (29 September 2017), https:/www.nytimes.com/2017/09/29/books/review/home-fire-kamila-shamsie.html ${ }^{25}$ Peter Morey, Islamophobia and the Novel (New York: Columbia University Press, 2018), 6-7.

${ }^{26}$ Peter Morey, 'Halal Fiction and the Limits of Postsecularism: Criticism, Critique and the Muslim in Leila Aboulela's Minaret', The Journal of Commonwealth Literature 53(2) (2018), 301-15, 302. 
${ }^{27}$ For example Monica Ali's 2003 realist novel Brick Lane was widely read as offering insight into the lives of Tower Hamlets' Bangladeshi community (see Ahmed, Writing Muslims, Ch. 4, especially 141-43).

${ }^{28}$ Morey and Yaqin, Framing Muslims, 193.

${ }^{29}$ Ibid., 195.

${ }^{30}$ Ibid., 195.

${ }^{31}$ Ibid., 196.

32 Tahmima Anam, 'Home Fire', in 'Best Books of 2017 - Part Two', Observer (26 November

2017). https://www.theguardian.com/books/2017/nov/26/best-books-of-2017-part-two

${ }^{33}$ Ahmed, Strange Encounters, 140.

${ }^{34}$ Young, Inclusion and Democracy, 224.

${ }^{35}$ For Muslims' susceptibility to racism, see Tariq Modood, Multicultural Politics: Racism, Ethnicity and Muslims in Britain (Edinburgh: Edinburgh University Press, 2005), 37-40 (although Modood doesn't emphasise the significance of the visual).

${ }^{36}$ Morey and Yaqin, Framing Muslims, 40.

${ }^{37}$ Ahmed, Strange Encounters, 24.

${ }^{38}$ Parvaiz's 'soundscapes' $(131,156)$ or 'aural map' (172) recall Shamsie's earlier novel

Kartography (London: Bloomsbury, 2003 [2002]), which explores storytelling as a form of mapping that can transgress the boundaries of cartographic maps.

${ }^{39}$ In her article about the novel, Claire Chambers underlines its focus on sound and listening: 'Sound and Fury: Kamila Shamsie's Home Fire', Massachussetts Review 59(2) (2018), 202-19.

${ }^{40}$ Ahmed, Strange Encounters, 155-56.

${ }^{41}$ Jack Straw, 'I Felt Uneasy Talking to Someone I Couldn't See', Guardian (6 October 2006),

https://www.theguardian.com/commentisfree/2006/oct/06/politics.uk

${ }^{42}$ Paul Gilroy, After Empire: Melancholia or Convivial Culture? (London and New York: Routledge, 2004), 166.

${ }^{43}$ Michel de Certeau, The Practice of Everyday Life, trans. Steven Rendall (Berkeley: University of California Press, 1984 [1988]), 92.

${ }^{44}$ Ibid., 93.

${ }^{45}$ The novel's concern with material borders and spaces in its depiction of the characters' encounters is also worthy of analysis but beyond the scope of this article.

${ }^{46}$ Ahmed, Strange Encounters, 145.

${ }^{47}$ Robert Eaglestone, Ethical Criticism: Reading After Levinas (Edinburgh: Edinburgh University

Press, 1997), 175; cited in Krishnan, 'Affect, Empathy, and Engagement', 221.

${ }^{48}$ Krishnan, 'Affect, Empathy, and Engagement', 220.

${ }^{49}$ Ibid., 228.

${ }^{50}$ Huggan, The Postcolonial Exotic, 39.

${ }^{51}$ James Procter, 'The Postcolonial Everyday', New Formations 58 (2006): 62-80, 66.

${ }^{52}$ Ibid.

${ }^{53}$ Procter, 'The Postcolonial Everyday', 67.

${ }^{54}$ Morey and Yaqin, Framing Muslims, 194.

${ }^{55}$ Examples of the visual as a positive means of asserting difference might include the Muslim 'veil' or beard, the Sikh turban or kara (bracelet) or kirpan (sword).

${ }^{56}$ Here my argument borrows from Brouillette's analysis of Derek Walcott's 'The Fortunate

Traveller', in Postcolonial Writers, 31-40, see especially 39.

${ }^{57}$ See Ahmed, Writing Muslims, Ch. 4, especially 141-43.

${ }^{58}$ See Kit De Waal, 'Don't Dip Your Pen in Someone Else's Blood: Writers and "the Other", Irish Times (30 June 2018), https://www.irishtimes.com/culture/books/don-t-dip-your-pen-in-someoneelse-s-blood-writers-and-the-other-1.3533819 


\begin{abstract}
:
This article explores the ethics of reading across difference in a secular literary marketplace that is increasingly invested in representations by and of Muslims. Focusing on Kamila Shamsie's Home Fire (2017), it considers how this high-profile novel anticipates and negotiates the pressures of anthropological reading practices, especially in its representation of the 'veiled' Muslim woman who can easily become a canvas for the projection of a liberal secular reader's ‘enlightened' self. Drawing on Sara Ahmed's work on 'strange encounters' to read the characters' encounters within the novel, the article highlights the novel's concern with the sensory everyday - especially the aural - as a possible means of bypassing the violence of surveillance and the visual more broadly in connecting with others. By examining these encounters, the article considers how the novel negotiates its implied reader's encounter with the text. It argues that while the success of Home Fire lies partly in its use of spectacular, even stereotypical images of Muslims, its overt theatricality in fact opens up a space beyond the frame within which Muslims are normatively seen or read, and enables a reading encounter that resists a transparent translation or easy consumption of difference. Through its analysis of Shamsie's novel, the article explores the possibility of building through reading what Iris Marion Young calls a 'differentiated solidarity' through reading - a means of forging connections across lines of difference (class and religiosity in particular) without compromising the 'distinction' of that difference - thereby intervening in debates about the ethics of writing and reading others.
\end{abstract}

Keywords:

Kamila Shamsie, Home Fire, British Muslims, performance, ethical reading, differentiated solidarity 
Towards an Ethics of Reading Muslims:

Encountering Difference in Kamila Shamsie's Home Fire

\section{Introduction}

In her study of residential segregation and regional democracy, Iris Marion Young argues for the importance of a 'differentiated solidarity', one that recognises and supports difference while also enabling productive communication and, potentially, political mobilisation across lines of difference. Young recognises the benefits of group clustering, especially for minority ethnic groups inhabiting western locations who can be supported and sustained by living together:

The social and political ideal of differentiated solidarity holds that segregation is wrong, but that social group distinction is not wrong. The ideal affirms a freedom to cluster, both in urban space and in religious, cultural, and other affinity group associations. This freedom should be balanced with a commitment to non-discrimination; spatial and social clustering, that is, cannot be based on acts of exclusion, but rather on affinity attraction. ${ }^{1}$

This balancing of the significance of the communal with the need to work against spatial structures of exclusion to facilitate communication across difference is crucial for recognising, and moving towards equality for, minority ethnic identities in multicultural British society. It works against the liberal tendency to relegate cultural difference to the private sphere and stigmatise minority subjects who choose to maintain their cultural practices within (and aided by) defined, but porous, boundaries. The idea of a differentiated solidarity is particularly important when considering Muslims in Britain, because of the distinction of Muslim cultural practices from majoritarian British culture, which marks their difference visibly, and because of their tendency to cluster physically which can be traced to 
social deprivation and 'white flight', as well as to a commitment to the preservation of certain modes of living. ${ }^{2}$ This has led to the levelling at Muslims of highly problematic accusations of 'self-segregation'. ${ }^{3}$ As well as working against such accusations, Young's concept retains an emphasis on the importance of forging links across the boundaries of community, which is central to a successful multiculturalism of reciprocity.

In this article, I draw on Young's theory to consider how we read across cultural and religious, as well as social and racial, difference. Specifically, Young's theory helps me think through how we might read across difference more ethically, and whether and how Kamila Shamsie's 2017 novel Home Fire facilitates an ethical reading of the British Muslim lives it depicts in the context of a literary marketplace which is increasingly invested in fictional representations of Britain's cultural diversity, ${ }^{4}$ and in which writing by and about Muslims has become a notable presence over the last decade. ${ }^{5}$ In this context, the importance of mediating Muslim identities and cultures to a heterogeneous but predominantly secular readership is in tension with the risk of facilitating an exoticising consumption of that difference, one which translates or dilutes difference into something that can be understood within, or assimilated to, normative (read: liberal and secular) paradigms. ${ }^{6}$ Here, I build on the work of Sarah Brouillette, Graham Huggan and Madhu Krishnan, which, in different ways, explores the way postcolonial writers mediate cultures and locations of the global South for an Anglo-American readership. Informed by this work, my article considers how Shamsie, an increasingly high-profile writer of Muslim heritage, negotiates the role of gatekeeper to 'her' community of difference for a diverse but predominantly white, middle-class and secular British readership in her most recent prizewinning novel. ${ }^{7}$ Shamsie is one of a handful of acclaimed 'Muslim' writers who combine their literary craft with journalistic writing for the British press, which positions them as public intellectuals and perhaps, uncomfortably, as 'native informants' ${ }^{8}$ Moreover, with 
Home Fire, Shamsie's fiction enters Britain and the realm of post-9/11 multicultural British politics and terror for the first time. Hence, the novel is particularly susceptible to anthropologically inflected readings that seek the 'truth' about British Muslims and radicalisation.

My focus is not on readers themselves, but rather on tracing the text's awareness of and anxieties about how it will be read, ${ }^{9}$ given its inevitable position as a 'literary mediator' of difference ${ }^{10}$ in a fraught context where Muslim 'others' are frequently the objects either of exclusionary and stigmatising discourses and practices, or of a well-intentioned curiosity that can tip into a fetishisation of difference. With reference to fictional representations of Africa, Krishnan writes that 'the aesthetic function of the literary text is always implicitly positioned alongside a parallel and pre-existing sociopolitical discourse of representation'. ${ }^{11}$ Shamsie, too, contends with the difficulty of writing Muslims 'under the spectre of the already-known', an image, or set of images, which hardly need rehearsing, and which can serve as a canvas for the projection of the spectator's enlightened secular self. ${ }^{12}$ In line with Bethan Benwell, James Procter and Gemma Robinson's call for the importance of developing an ethics of reading, ${ }^{13}$ my concern is to explore how the novel negotiates conflicting pressures in its attempt to facilitate an ethical reading, one which disturbs 'dichotomous divisions' between reader and subject, 'saviour' and 'victim', or 'self and other'. ${ }^{14}$ Young's notion of differentiated solidarity helps illuminate and more sharply define an ethical reading as one that disables an easy consumption of cultural difference, while nevertheless retaining the possibility of communicating that difference to the reader effectively, in order to create the potential for some form of solidarity across difference. In other words, reading across difference in an ethical and politically resistant manner entails both a recognition and affirmation of the 'distinction' of difference (that it resists translation into transparency and defies an 'anthropological' mode of reading) and an openness to 
connecting with that difference and readiness 'to be changed by what it has to offer'. ${ }^{15} \mathrm{My}$ reading of Home Fire, then, will focus on the encounters that take place between the central characters to consider how the novel negotiates its implied reader's encounter with the text. Framed by Sara Ahmed's work on ethical modes of encountering others, it asks, crucially, whether and how the novel interpellates its reader in a way that 'resist[s] thematising [Muslim] others as "the other", ${ }^{16}$ while nevertheless forging connections across difference, thereby building a differentiated solidarity through reading.

\section{Surveillance and performance}

In this section of the article, I consider Home Fire's exploration of ways of surveilling or reading Muslims. This exploration, I argue, reveals its own self-consciousness about how its depiction of Muslims might be read. By scrutinising modes of viewing others, the novel directs the reader's attention towards their own readerly gaze, encouraging a more selfconscious way of reading. Further, by departing increasingly from realist conventions towards a more spectacular, theatrical style, the novel distances its reader from its Muslim subjects and deflects an anthropological mode of reading which can limit western, nonMuslim responses to fictional representations of Muslims. In these ways, the novel helps us think through what might constitute a more ethical mode of reading across difference.

Home Fire takes surveillance as one of its key concerns. Most obviously, it is concerned with the impact of MI5's surveillance of siblings Isma, Aneeka and Parvaiz Pasha, first because of their father's radicalisation and consequent detention at Bagram before his death in transit to Guantánamo Bay, and later because of Parvaiz's own recruitment to the 'media wing' of Islamic State in Syria. ${ }^{17}$ Yet, beyond this, the novel incorporates the monitoring by and of Muslim Conservative MP Karamat Lone in London, as well as Isma's subjection to 
interrogation before boarding her flight to the US (3-7), the siblings' monitoring of each other's movements on Skype (30-31), the media's surveillance of Aneeka after Parvaiz's death (188-92, 197-8, 201, 204, 206-7), and Karamat's privileged son Eamonn's scrutiny of his lover Aneeka, who seduces Eamonn in order to gain influence with his powerful father in the hope that he will help bring home her beloved twin Parvaiz. It is with the latter, which operates partly through the trope of the veil, that the interplay of surveillance and subterfuge is most compellingly explored, in ways which cast light on the politics of writing and reading Muslims.

In her seminal reading of the western fascination with veiling practices in the Muslim world, Meyda Yeğenoğlou explores how the elusive nature of the veiled Muslim woman incites in the (white, colonial) man a desire to transform her difference into 'a manipulable and enjoyable object of discourse' in order to provide himself with 'a sense of the fictive unity and command of his experience'. ${ }^{18}$ For Yeğenoğlou it is precisely the assumed unknowability of the veiled woman that threatens the viewer's command of knowledge and elicits their need to decipher her. In the contemporary British context, this drive to read visible markers of Muslim difference - and assumed inscrutability - as transparent symbols is evident in the frequent 'decoding' of the 'veil' or beard as signifying specific characteristics, whether patriarchal religious oppression, cultural separatism, radicalism, or a combination of these. This need to impose a singular reading on Muslims, then, reveals the anxiety of the viewer or reader when confronted by religious difference. Hence, the inscrutability attributed to the Muslim subject can be reconfigured as a projection of the observer's own incomplete vision, destabilising the authority of their surveillance or reading practices. Reconfiguring the encounter in this way enables the Muslim subject to withhold the distinction of their difference from scrutiny, labelling and consumption. 
In Eamonn's narrative, the second of five parts or 'acts' in this contemporary reworking of Sophocles' Antigone, Aneeka's presence dominates, with her hijab frequently forming the focus. Despite Eamonn's part-Muslim heritage (he is of Pakistani and white Irish American descent), his gaze is clearly exoticising, at times reducing Aneeka to the double-sided Orientalist stereotype of the veiled Muslim woman as chaste yet lascivious, inaccessible yet promiscuous, mysterious yet the ultimate object of knowledge. ${ }^{19}$ In a series of images, her religiosity, emblematised by her hijab, overlays her sexualised body. When Eamonn meets her, his first thought is 'how he might use [his greasy fingers] to unpin the white hijab that framed her face' (64). Back at his Notting Hill apartment, he observes her unpinning her hijab to let down her long, dark hair, 'like something out of a shampoo advertisement' (68); while shortly afterwards, the image of her at prayer, with a 'scarf loosely covering her head', is spliced with one of her 'down on her knees for a very different purpose' (70). This sequence builds to a crescendo as Aneeka offers herself to Eamonn naked but for 'the white scarf covering her head, one end of the soft fabric falling just below her breast, the other thrown over her shoulder', purposefully playing to his fantasies (71). While Aneeka literally unravels her hijab to make herself sexually available to Eamonn, the mystery of her is not unravelled, and she remains 'unreadable' or inscrutable to him $(84$; see also $77,85,74)$. Of course, the reader knows that Aneeka is purposefully withholding knowledge about herself and her motivations from Eamonn. The fact that her apparent elusiveness is in reality an intentional act partly dismantles the stereotype of the inscrutable Muslim woman with which Eamonn fixes her. Eamonn, moreover, is constructed as naïve and disempowered. If the supposed unknowability of the veiled Muslim woman incites in the observing privileged, secular man a seductive desire to fix her difference, or transform it into a knowable object, to attain 'a sense of the fictive unity and command of his experience', then, in the case of Eamonn, this process of transformation, objectification and command is thwarted. ${ }^{20}$ Indeed, 
Aneeka performs for Eamonn, constructing a persona for his fantasies but for her interests, and it is she, therefore, who assumes the position of command, subverting the relationship of power that connects them. While the reader is privy to Eamonn's curiosity about Aneeka and his attempts to 'read' her, it is arguably Aneeka who is the more confident reader of Eamonn. Aneeka's material veil, then, symbolises her ability to 'look without being seen' and to 'turn [herself] into a surveillant gaze'. ${ }^{21}$ As Yeğenoğlou points out, '[i]t is in this space of absent-presence that there emerges the challenges of the "invisible", "hidden" other'. In other words, it is here that the possibility of resistance can be located. Further, this resistance, as well as thwarting the western, secular subject's knowledge, also works to 'destabilize the identificatory process of the subject' himself, ${ }^{22}$ or to disturb his sense of a coherent self. Just as Yeğenoğlou refocuses the spotlight from the object of western fantasies to the observing subject, so the novel scrutinises Eamonn (scrutinising Aneeka). What is under surveillance here, then, is not practices of veiling, or Islam more broadly, but what Peter Morey and Amina Yaqin describe as 'the locus of misrecognition' ${ }^{23}$ the viewer whose vision is flawed and whose self is split.

As well as resisting Eamonn's knowledge, Aneeka remains elusive to the reader. Notably, Aneeka's own narrative strand is packed with other voices, especially voices from the media. Of the nineteen short fragments that make up the narrative, four are extracts from different kinds of newspaper report, two are snapshots from Twitter threads, one is composed entirely of speech, and another is a short poem. The media voices are reductive and pernicious to varying degrees, distorting the histories and realities of the lives of the Pasha family, and violating their privacy, with the headline of the final, tabloid-style article declaring 'Hojabi! Pervy Pasha's Twin Sister Engineered Sex Trysts with Home Secretary's Son' (204). Given the novel's roots in Sophocles' Antigone, these voices could be understood as performing the role of the Chorus in a Greek tragedy, guiding the audience to 
a certain reading of events. Yet, their clear distortion instead places the onus on the reader to read individually and critically, beyond media soundbites and stereotypes. Where we do gain access to Aneeka's voice, at times this is in note form: the narrative feels rushed, frequently omitting the subject ('she'), as if it is reflecting the erosion of her selfhood that she experiences on learning of her twin brother's death, or her single-minded resolve to bring his body home, or perhaps her own limited voice as a working-class visibly Muslim woman. Yet, an effect of this is to distance the reader. While in the final section of the novel, told from Karamat's perspective, Aneeka is also a focal point, here, too, she is distanced both from Karamat and from the reader. In an attempt to bring her dead brother back to Britain, Aneeka engages in a highly stylised form of consecration and preservation of his body. Equipped with an ice coffin, rose petals, and a white sheet, her self-conscious performance is doubly mediated - first by the cameras that are filming her in Islamabad, and second by Karamat's interpretation of the images he watches on television, with the sound significantly muted. The layers of mediation serve to keep the reader at bay, along with Karamat and members of the viewing public, eager for corroboration of what they 'know' about Muslim women. While we can see beyond the name-calling of the tabloids - 'Slag, terrorist-spawn, enemy-of-Britain' (229) - we are left with an elusive subject. In this sense, the 'surveillant gaze' on her is subverted, or at least undermined; she is doubly, or perhaps triply, veiled.

The failure, or partiality, of readerly identification with Aneeka is all the more striking when contrasted with the novel's opening section which is focalised through Isma. Here, the use of free indirect discourse to render, in realist mode, Isma's experience of travelling to Massachusetts, navigating life there, and falling in love, in the wake of her brother's departure for Syria, enables an emotional transaction between the reader and a young observant Muslim woman. Thereafter, this transaction is increasingly denied the reader, as 
Isma recedes from the narrative and Aneeka, rendered at a distance, through layers of mediation, assumes centre stage, culminating in the self-conscious theatricality of her presence in the novel's final 'act' which inclines towards melodrama. Indeed, Peter Ho, in his review of the novel, comments on the 'stagy' quality of its final 'act', and the 'distancing effect' of this 'stylistic shift' to self-conscious theatricality. ${ }^{24}$ While this distancing of Aneeka might lend itself to the neo-Orientalist construction of the Muslim woman as inscrutable, arguably the layers of mediation disable consumption of her difference by readers both within and of the text. In this sense, the narrative can be understood as resistant to the demands of the western secular reader to 'know' the Muslim woman. The proliferation of both fiction and memoirs by writers of Muslim heritage in the decade following 9/11 points to a readership eager for such 'knowledge', which in turn exerts pressure on Muslim writers to produce 'authentically' representative fictions. ${ }^{25}$ In an article on Leila Aboulela's 2005 novel Minaret, Peter Morey comments on the 'unvarnished realism' of this practising Muslim writer's work, which, he argues, 'attempts to conciliate what might be called "anthropological" readings of Muslim writing, which see texts by an avowedly religious subject as offering insights into the mind of the "other"', ${ }^{26}$ Aboulela is certainly not the only writer whose work has been read in this way. ${ }^{27}$ Shamsie's novel, I argue, problematises this mode of reading. It is precisely through its theatricality that the novel eschews the anthropological, deflecting readings which interpret fictional Muslim characters and communities as representative of their culture or faith. By foregrounding the layers of mediation through which we observe the other, the narrative withholds an 'authentic' Muslim subject, placing in metaphorical scare quotes the at times familiar, even hackneyed images it offers us, as well as encouraging us to reflect on our own reading practices. 
In Framing Muslims, Morey and Yaqin discuss the notion of 'parodic performance' or 'hyperperformativity', ${ }^{28}$ applying it to the work of Pakistani British comedian Shazia Mirza in particular. While the theatricality that emerges increasingly in Shamsie's novel is not 'parodic', the idea of hyperperformance is helpful in illuminating the politically subversive potential of the novel's melodramatic 'staginess', especially in its representation of Aneeka. Reading Mirza through the work of Judith Butler, Morey and Yaqin maintain that just as the performance or masquerade of femaleness "can be "troubled" by its "subversive repetition" and "parodic recontextualisation"”, so Mirza's post-9/11 hyperperformance of a hijab-clad Muslim woman 'operated as masquerade - raising questions about whether "Muslimness" could be finally identified and pinned down or in fact was always being confused with its outward signifiers'. ${ }^{29}$ In other words, it pointed to the gap between image and an undefineable reality. They go on to assert that 'Mirza was encoding the cultural identity of Muslimness as it was perceived by the viewer: in other words, she was subverting a stereotype by employing, repeating, and exaggerating it' - thereby 'calling into question any idea of an "original" truth behind the image'. ${ }^{30}$ Not only does such hyperperformativity debunk the very notion of authenticity, then, it also refocuses the spotlight on the viewer, or in this case the reader, as the 'locus of misrecognition', rather than on 'Muslimness' itself. ${ }^{31}$ Just as it is Eamonn's 'misrecognition' or failed reading of Aneeka that forms the focus of his narrative strand while Aneeka herself remains largely unknowable, concealed beneath her performance, so it is our own observation or (mis)reading that is placed within the frame of the novel's final section. It is in this sense that the novel can be seen to reference but avoid repeating the stereotype of the inscrutable veiled Muslim woman.

Tahmima Anam hints at a subversion of an anthropologically inclined reading of the novel when she writes of Home Fire: 'it managed to ... give me a tiny glimpse into the otherness of others'. ${ }^{32}$ In other words, this subversion works to "protect or preserve the otherness of 
the other' by deflecting or resisting commodification or consumption. ${ }^{33}$ When a representative from the Pakistan High Commission in London visits the Pasha family to inform them of Parvaiz's death, Aneeka, in a state of denial and shock, tells him: 'He wasn't one of yours ... we aren't yours' (184). The meaning of these words becomes clearer in a subsequent exchange with the official in which she refutes the Pakistani identity ascribed to them and lays claim to British citizenship. But the fact that they first appear decontextualized and open to interpretation suggests a more general refusal to be fixed by definitions and labels imposed by others (whether 'terrorist' or 'jihadi', 'niqabi' or 'hijabi'), and an assertion of their autonomy and right to self-definition within Britain. Further, the last three words - 'we aren't yours' - might also be read as an address to the reader, a refusal to be translated for easy consumption by the white, secular, middle-class reader in particular. Here, we might return to the adaptation of Young's notion of a differentiated solidarity, which I outline above. If - extrapolating from Young's contention that 'social group distinction', ${ }^{34}$ or more broadly the retention of cultural difference, positively enables minority subjects - reading difference ethically entails a recognition of the 'distinction' of difference, then arguably Shamsie's novel facilitates such a reading practice by retaining the opacity of that difference and thereby obstructing its anthropological consumption.

\section{Ethical encounters}

This section reads further encounters in the novel as a way to think some more about readers' encounters with the text and the novel's own anxieties about and negotiation of the ethics of reading across difference. Coupled with Home Fire's emphasis on performance and the spectacular as a means of deflecting anthropological reading practices, is an exploration of how we might read others more ethically by engaging our other senses. 
Drawing on Sara Ahmed's work on 'strange encounters', I highlight the novel's concern with the sensory everyday - especially the aural - as a possible means of bypassing the violence of surveillance and the visual more broadly in connecting with others. While moments of real connection between the novel's protagonists are rare and fleeting, I argue that Home Fire's deflection of anthropological, appropriative readings creates a productive unease for readers, which, combined with the novel's decentred intra-Muslim perspective, moves some way towards breaking down a 'them and us' dichotomy between secular western readers and the text's Muslim subjects, facilitating a more ethical mode of reading. The novel's emphasis on performance and surveillance highlights the role of the visual in shaping or entrenching perceptions of others, and thereby entrenching barriers between cultural groups, or impeding communication across them. It is the visibility of their difference in the public sphere - whether this takes the form of veiling or prayer in schools or courts of law, or a community whose infrastructure is dominated by services that cater for its religious culture - that makes British Muslims especially susceptible to racism. ${ }^{35}$ Morey and Yaqin describe how British Muslims 'find themselves in ... a double bind of performativity' as they are called upon to perform both their 'Britishness' and their 'Muslimness' in the public sphere. ${ }^{36}$ Notwithstanding his class privilege, Karamat Lone's public role places increased pressure on him to perform 'Britishness' or the 'good Muslim' for the public eye. For example, caught entering a mosque associated with a 'hate preacher', he responds by publicly walking into a church with his wife in order to assert his 'Britishness' (35), thereby winning votes from his white constituents while alienating Muslims. Eamonn echoes his father's cultural and spatial navigation when on his way to Aunty Naseem's: he crosses a road to avoid walking past a mosque, then crosses back 'so as not to be seen as trying to avoid a mosque' (59). Of course, it is not visible cultural difference itself that cause divisions - as Karamat would have it (87) - but rather the 
surveillant gaze that fixes the religious 'other', consigning them to a particular, boundaried place. As Sara Ahmed writes, the recognition of others 'operates as a visual economy: it involves ways of seeing the difference between familiar and strange others as they are (re)presented to the subject. As a mode of subject constitution, recognition involves differentiating between others on the basis of how they "appear". 37

In the light of this, we might read Parvaiz's preoccupation with sound as signalling to the reader the potential, or at least the need, for a means of communicating across difference that bypasses the distorting properties of the image and the violence of surveillance. While Karamat turns the sound off when viewing images of Aneeka mourning her brother, Parvaiz privileges sound over vision in his reading of the world. Indeed, in the soundscape that he creates from the roof of his garden shed, a 1,440 track 'of every minute of a day ... recorded over 1,440 days', the only fragments of speech are every-day, almost banal comments belonging to Aneeka (131). ${ }^{38}$ This points to the limits of language, too: the labels 'terrorist' and 'jihadi' immediately conjure images which fail to capture the complex reality of Parvaiz; while the seductive power of the decontextualized, fragmented images of Adil Pasha helps to misdirect his son towards a future he does not want. Yet, for the aural to circumvent the travesties of the visual, hearing must entail listening. ${ }^{39}$ While working as a sound engineer for IS, Parvaiz is at first partly successful in his attempt to abstract the sounds he hears with such precision from their horrific meaning (170), which only becomes insufferably clear once he begins to listen. If seeing lures Parvaiz into IS, listening makes him leave $(145-59,174)$. Aneeka, too, with the repeated phrase of 'Hear that', teaches Eamonn how to 'listen to the sounds of the world': she encourages him to record the time he spends without her, to bring her the 'soundscape of [his] days' (89). In this respect, the novel's injunction is, broadly, to listen closely, to interpret what we hear with care, 
especially when the cultural other is speaking, in order to move through the reductive signs and symbols that seduce or repel, or do both together.

Indeed, it is not insignificant that it is the aural that takes Karamat into a borderline space when Isma visits him in his home. When Isma accidentally activates the ice-cube dispenser on Karamat's fridge, its noiselessness recalls for him 'the rattling, groaning ice dispenser in the fridge door of one of the Wembley relatives' of his childhood (235), taking him into an uncanny space of familiar difference. For the discomfort Karamat feels in Isma's presence is not primarily because of the social chasm between them, but rather because of her familiarity. When she looks at him, 'something passed between them - it wasn't about sex, but something that felt more dangerous. She was familiar to him, a reminder of a world he's lost' (238). The aural reminder of the ice cubes disrupts the visual by forcing Karamat to connect with Isma as someone familiar, beyond the image of a 'hijabi' or an object of desire. It takes Karamat into a space of productive dissonance or discomfort - one that has the potential to enable an encounter across lines of difference, or beyond the frame. The ice cubes recall two earlier scenes in the novel. The first is the curious sound of ice falling on icicles outside Hira Shah's Amherst apartment which enables Isma to recall her brother lovingly, beyond the image of the IS recruit that she has had to reduce him to (12); the second is Adil Pasha dipping his head into a Chechnyan mountain stream to perform his ablutions and emerging with a beard full of icicles which 'produced the sound of wind chimes', and evokes, for Parvaiz, 'the father he'd never known' (128). In both cases, the sound of ice serves as a kind of fracture in the visual, a means of getting beyond a static image (of 'terrorist' or 'hijabi'), and thereby forging a connection with an other. The novel's focus on sound recalls Sara Ahmed's exploration of hearing in encounters across difference. For Ahmed, '[t]o hear, or to give the other a hearing, is to be moved by the other, such that one ceases to inhabit the same place'. ${ }^{40}$ In other words, it is hearing, or listening, that 
facilitates movement beyond one's own place, to a space or discomfort, where one is out of place. Further, it is precisely by acknowledging the necessity of gaps in communication, or the importance of 'that which fails to get across', that an ethical encounter can take place. Or, put differently, it is through retaining an element of distance from the other that closeness can be facilitated. Ahmed continues:

What allows us to face each other ... is also what allows us to move beyond the face, to hear and be touched by what we cannot grasp, as that which cannot be assimilated in a moment of recognition of either 'the Other' or the stranger. (158)

Hence, in encounters across difference, she encourages us to move beyond what we can see - the images that can work to fix people into stereotypes - to engage our other senses, touch as well as hearing, in order to avoid the trap of assimilating or translating difference into the familiar. By doing so, we might open ourselves up to the 'distinction' of that difference, in line with Young's notion of a 'differentiated solidarity'. In the case of an encounter between a niqab-clad Muslim woman and her secular white interlocutor, then, Ahmed's thinking might encourage the latter not to ask to see her face, but to look beyond the fact that it is covered, perhaps by listening. ${ }^{41}$ To apply Young's theory, a connection - towards solidarity - is made by respecting her difference, not by attempting to diminish or appropriate it.

The sounds captured in Parvaiz's recordings and in the recordings Eamonn makes for Aneeka, as well as the ice cubes that take Karamat back to his childhood, point to the significance in the novel of the everyday as a potential means of forging connection across difference. Indeed, as in these examples, it is often the sensory everyday that enables connections. So, for example, in one of their early meetings in an Amherst cafe, Eamonn asks Isma to find a Pakistani pop song that takes him back to the Wembley interludes in his privileged childhood, before the two share a plate of food, a sign of their 'intimacy' or 'comfort' with one another, captured in one of the few Urdu expressions Eamonn knows, 
'bay-takalufi' (28-9). The idea of food as an everyday vehicle for transgressing social and cultural boundaries recurs when Eamonn visits Aunty Naseem's house and is served samosas which he thanks her for with the Urdu word 'Shukriya', an incident in which sound and taste again combine to displace him into a distant part of his childhood (62); when Eamonn and Aneeka pit and eat cherries together in Eamonn's rooftop garden in a scene marked by touch and sensuality (92-3); and when, on the cusp of the fracturing of their family, Aneeka cooks dinner, aided by Parvaiz, to the sounds of South Asian music, the hum of the refrigerator, a train pulling out (117). If the emphasis on hearing primarily, but also taste and touch, suggests the potential for bypassing the divisive effects of the visual, the focus on the everyday is redolent of Paul Gilroy's notion of conviviality, the 'emancipatory interruptions' that can occur in contemporary British multiculture and that are defined precisely by their banality and ordinariness. ${ }^{42}$ Indeed, the everyday is also a vehicle for subverting and disrupting boundaries for Michel de Certeau. In his conceptualisation of urban space and the way we navigate it, de Certeau underlines the role of the visual in imperialistic practices of mapping, which contrasts with the necessary blindness of subversive practices that can cut across cartographic borders. ${ }^{43}$ For de Certeau, the 'ordinary practitioners of the city' live 'below the thresholds at which visibility begins ... These practitioners make use of spaces that cannot be seen; their knowledge of them is as blind as that of lovers in each other's arms'. ${ }^{44}$ We might consider Aneeka and Eamonn's encounters, as well as other characters' encounters which take them fleetingly into uncanny spaces of productive dissonance, in these terms; ${ }^{45}$ and we might read the novel's interest in the sensory everyday as a means of exploring the possibilities for communicating across material lines of difference and beyond the visual - possibilities that do not, however, become realities. 
With its focus on failed encounters, then, the novel seems to suggest the difficulty of moving beyond the frames which constrain British Muslims, at least in the present. Yet by drawing attention to the surveillant pressures operating on Muslims, both through its rendering of encounters between characters, and through its increasing artifice, or theatricality, which turns the spotlight on the reader's encounter with the characters, Home Fire opens up a space for reflection, beyond the stereotypes that it deploys. It could even be said that by withholding an authentic 'Muslimness' and refocusing the spotlight on the reader, the text pulls the latter into its frame, thereby breaking down the self/other dichotomy between reader and characters, and enabling some connection across difference. In this sense, the reader is made to occupy an uncomfortable position within the text, the productively uncanny space that Karamat momentarily occupies in his encounter with Isma. In her reading of literary representations of Africa, Krishnan emphasises the importance of 'an understanding of non-understanding', a suspension of the need to 'understand' difference, as a way of carving out a 'space within which to form an ethical existence' or an ethical reading position. In Home Fire, the 'mode of encounter', of reader and text, does not 'hold the other in place, or ... turn her into a theme, concept or thing'. ${ }^{46}$ Rather, the reader is 'made to feel not at home with the text or in [them]selves', ${ }^{47}$ and it is this unhomeliness wherein lies the possibility for moving towards a partial fracturing of exclusionary notions of 'them' and 'us' which define who can and who cannot feel at home in Britain.

Within Home Fire, all of the significant encounters are between British Muslims, rather than between Muslims and white secular Britons. The novel's concern with British Muslims' failed communication with one another shifts the focus partly from cultural and religious difference to class difference - for while the characters are divided also by the extent of their religiosity, arguably this is shaped primarily by class $(18,91)$. An effect of the novel's all-Muslim cast is to underline the heterogeneity of British Muslims, and so break down the 
dichotomy between non-Muslims and Muslims. A further effect is, arguably, to break down the division between Muslim object of reading and secular reading subject. Drawn into a network of different Muslim characters who are often 'reading' or misreading each other, the reader is denied an extended relationship of empathy with a single dominant narrator or focalising character - which in turn minimises what Krishnan, citing Marcus Wood, describes as the danger of "fall[ing] into self-interested "appropriative empathy", ${ }^{48}$ of developing an affective connection with a character that in fact fetishizes or appropriates their difference and reduces them to the 'already-known', ${ }^{49}$ while 'mask[ing]', or at least attenuating, 'the inequality of the power relations' that structure the world we share. ${ }^{50}$ In this way, the decentred intra-Muslim perspective facilitates a more ethical mode of reading.

\section{Building a 'differentiated solidarity' through reading}

In his article 'The Postcolonial Everyday', James Procter explores the 'cultural work everyday expressions might perform at a moment when Asian experience seems increasingly bifurcated from English daily life'. ${ }^{51}$ Noting the prevalence in cultural representations of 'extreme, extraordinary versions of South Asian culture in the UK since 9/11', which are, as he puts it, 'split between exoticism and fanaticism, between the fetish for difference and the fear of terrorism', he investigates the ways in which a body of British Asian films presents a productively 'mundane' alternative. ${ }^{52}$ On the surface, Shamsie's novel immerses itself in 'exoticism' and 'fanaticism', the sensationalist images and discourses that characterise cultural representations of British Asians (particularly those of Muslim heritage), even while it draws attention to and arguably undermines such images and discourses, through its focus on the everyday as an avenue for facilitating meaningful communication, as well as its theatricality. The novel's allusion to the phrase 'Keep the 
home-fires burning', the title of a patriotic First World War song, most obviously connotes the exclusionary understanding of Britain as home - one which is underpinned by continuing patriotism or imperialistic nostalgia, and one which is denied to Parvaiz, both living and dead. Yet the title also carries within it the tension between the spectacular images on which the novel trades and its concern with undermining these: while 'home' is, as Procter describes, a 'privileged symbol of the everyday', 53 'fire' evokes the terroristic violence that is the most obvious subject of the novel. While it critiques the surveillant gaze which freezes Muslim subjects, particularly visibly Muslim women and young disenfranchised Muslim men, into stereotypical images, it also inevitably benefits from its investment in these images that can so easily be read to corroborate the 'extreme, extraordinary versions of South Asian [Muslim] culture' that Procter outlines - images that tip into melodrama and sell books in the literary marketplace. In particular, the melodrama of the novel's final scene, in which the lovers are reunited only to face a violent death, might be read as corroborating the corrosive stereotypes that circulate. Hence, the novel treads a dangerous path. Echoing but adapting Morey and Yaqin's interrogation of the use of hyperperformativity in Shazia Mirza's comedy, we might ask how far 'the strategic assimilation and deliberate transgression of [such] stereotypes' takes us beyond them, especially given how susceptible they are to misreading. ${ }^{54}$

Further, while the novel's use of performativity highlights the dangers of the surveillant gaze, the fact that the Pasha siblings are reduced almost to a series of silent masks by the end of the novel - Aneeka most obviously, while Isma fades away, and Parvaiz's corpse is masked in ice - remains troubling. In a sense, their 'Muslimness' is diminished to the point that it becomes barely more than the silent object of the gaze, leaving little space for a positive assertion of visibly cultural difference in the novel, or for the speech that is required to make listening effective and dialogue possible. ${ }^{55}$ Yet, I read this as a consequence of the 
novel's reluctance to speak for a community of difference. For if Eamonn occupies a peripheral position in relation to the Pasha family, Shamsie herself occupies a peripheral position in relation to the characters and community she renders. Indeed, the difficult encounters between the characters, the breakdown in communication which marks them, also points us to the uneasy position occupied by a narrative authored by an elite cosmopolitan Muslim that attempts to translate working-class Muslim lives to a middleclass white secular reader. ${ }^{56}$ As I've argued elsewhere, literary controversies involving minority religious communities in Britain, such as that surrounding Monica Ali's novel Brick Lane, ostensibly about religious offence, can concern ownership, too - or, more specifically, the feeling of being disowned by an elite cultural representation of a community, particularly one that either claims to be or is perceived as representative or even 'authentic'. ${ }^{57}$ While recent debates around cultural appropriation have tended to centre on racial difference (white writers rendering minority ethnic characters), we might legitimately bring class and religiosity into the mix, to explore the ethics of a privileged secular writer depicting the lives of her under-privileged religiously observant counterparts who have less access to representation, or less freedom to speak. ${ }^{58}$ If, as I've argued, Shamsie's novel withholds 'ownership' of the characters from the reader through its increasing theatricality, we might read in this an anxiety or unease about the ethics of writing and reading across lines of difference, about how a writer can avoid taking ownership of, or speaking for, a community from which they are distanced through privilege despite an affiliation. Home Fire navigates this perilous terrain by giving the reader access to a cast of British Muslims, while at the same time denying the reader an appropriative consumption of their 'Muslimness' through an increasingly exaggerated, melodramatic style which disturbs a reading of the characters as 'authentic'. In this way, the novel encourages readers to recognise the distinction of the difference they encounter as well as to reflect on their own 
practices of reading across difference. The reader is displaced in a sense - or denied their usual way of reading a representation of British Muslims - and this displacement is a first step towards being receptive to and therefore communicating effectively across difference, in order to build a differentiated solidarity through reading.

Wordcount: 8365 
${ }^{1}$ Iris Marion Young, Inclusion and Democracy (Oxford: Oxford University Press, 2000), 224.

${ }^{2}$ Rehana Ahmed, Writing British Muslims: Religion, Class and Multiculturalism (Manchester: Manchester University Press, 2015), 4, 32-33.

${ }^{3}$ See Tahir Abbas, 'British South Asian Muslims: Before and After September 11', in Muslim Britain: Communities Under Pressure, ed. Abbas (London and New York: Zed Books, 2005), 3-27, $12,4$.

${ }^{4}$ Claire Squires, 'Too Much Rushdie, Not Enough Romance? The UK Publishing Industry and BME (Black Minority Ethnic) Readership', in Postcolonial Audiences: Readers, Viewers and Reception, ed. Benwell, Procter and Robinson (London and New York: Routledge, 2012), 99-111.

${ }^{5}$ Rehana Ahmed, Peter Morey and Amina Yaqin, 'Introduction', in Culture, Diaspora, and Modernity in Muslim Writing, ed. Ahmed, Morey and Yaqin (London and New York: Routledge, 2012), 1-17, 1-2.

${ }^{6}$ Graham Huggan, The Postcolonial Exotic: Marketing the Margins (London and New York: Routledge, 2001), 13-14, 27.

${ }^{7}$ Home Fire won the 2018 Women's Prize for Fiction.

${ }^{8}$ This is not to suggest that Shamsie's journalism is confined to 'Muslim' matters; in fact, its subject matter is notably wide-ranging.

${ }^{9}$ Sarah Brouillette, Postcolonial Writers in the Global Literary Marketplace (Basingstoke: Palgrave, 2007), 4, 6-7.

${ }^{10}$ Ibid., 39.

${ }^{11}$ Madhu Krishnan, 'Affect, Empathy, and Engagement: Reading African Conflict in the Global Literary Marketplace', The Journal of Commonwealth Literature 52(2) (2017), 212-230, 213.

${ }^{12}$ Ibid., 228.

${ }^{13}$ Bethan Benwell, James Procter and Gemma Robinson, 'Introduction', in Postcolonial Audiences: Readers, Viewers and Reception, ed. Benwell, Procter and Robinson (London and New York: Routledge, 2012), 1-23, 16-18.

${ }^{14}$ Krishnan, 'Affect, Empathy, and Engagement', 220

${ }^{15}$ Derek Attridge, 'Responsible Reading and Cultural Distance', in Postcolonial Audiences: Readers, Viewers and Reception, ed. Benwell, Procter and Robinson (London and New York: Routledge, 2012), 234-44, 235.

${ }^{16}$ Sara Ahmed, Strange Encounters: Embodied Others in Post-Coloniality (London and New York: Routledge, 2000), 141.

${ }^{17}$ Kamila Shamsie, Home Fire (London: Bloomsbury, 2017). All references to this edition of the novel will be given in the body of the article.

${ }^{18}$ Meyda Yeğenoğlou, Colonial Fantasies: Towards a Feminist Reading of Orientalism (Cambridge: Cambridge University Press, 1998), 47.

${ }^{19}$ See Yeğenoğlou, Colonial Fantasies.

${ }^{20}$ Ibid., 47.

${ }^{21}$ Meyda Yeğenoğlou, 'Veiled Fantasies: Cultural and Sexual Difference in the Discourse of Orientalism', in Feminist Postcolonial Theory: A Reader, ed. Reina Lewis and Sara Mills (London and New York: Routledge, 2003), 542-66, 557.

${ }^{22}$ Ibid., 555-57.

${ }^{23}$ Peter Morey and Amina Yaqin, Framing Muslims: Stereotyping and Representation After 9/11. (Cambridge, Mass.: Harvard University Press, 2011), 196.

${ }^{24}$ Peter Ho, 'An "Antigone” for a Time of Terror', The New York Times (29 September 2017), https://www.nytimes.com/2017/09/29/books/review/home-fire-kamila-shamsie.html ${ }^{25}$ Peter Morey, Islamophobia and the Novel (New York: Columbia University Press, 2018), 6-7.

${ }^{26}$ Peter Morey, 'Halal Fiction and the Limits of Postsecularism: Criticism, Critique and the Muslim in Leila Aboulela's Minaret', The Journal of Commonwealth Literature 53(2) (2018), 301-15, 302. 
${ }^{27}$ For example Monica Ali's 2003 realist novel Brick Lane was widely read as offering insight into the lives of Tower Hamlets' Bangladeshi community (see Ahmed, Writing Muslims, Ch. 4, especially $141-43$ ).

${ }^{28}$ Morey and Yaqin, Framing Muslims, 193.

${ }^{29}$ Ibid., 195.

${ }^{30}$ Ibid., 195.

${ }^{31}$ Ibid., 196.

${ }^{32}$ Tahmima Anam, 'Home Fire', in 'Best Books of 2017 - Part Two', Observer (26 November 2017). https://www.theguardian.com/books/2017/nov/26/best-books-of-2017-part-two

${ }^{33}$ Ahmed, Strange Encounters, 140.

${ }^{34}$ Young, Inclusion and Democracy, 224.

${ }^{35}$ For Muslims' susceptibility to racism, see Tariq Modood, Multicultural Politics: Racism, Ethnicity and Muslims in Britain (Edinburgh: Edinburgh University Press, 2005), 37-40 (although Modood doesn't emphasise the significance of the visual).

${ }^{36}$ Morey and Yaqin, Framing Muslims, 40.

${ }^{37}$ Ahmed, Strange Encounters, 24.

${ }^{38}$ Parvaiz's 'soundscapes' $(131,156)$ or 'aural map' (172) recall Shamsie's earlier novel

Kartography (London: Bloomsbury, 2003 [2002]), which explores storytelling as a form of mapping that can transgress the boundaries of cartographic maps.

${ }^{39}$ In her article about the novel, Claire Chambers underlines its focus on sound and listening: 'Sound and Fury: Kamila Shamsie's Home Fire', Massachussetts Review 59(2) (2018), 202-19.

${ }^{40}$ Ahmed, Strange Encounters, 155-56.

${ }^{41}$ Jack Straw, 'I Felt Uneasy Talking to Someone I Couldn't See', Guardian (6 October 2006), https://www.theguardian.com/commentisfree/2006/oct/06/politics.uk

${ }^{42}$ Paul Gilroy, After Empire: Melancholia or Convivial Culture? (London and New York: Routledge, 2004), 166.

${ }^{43}$ Michel de Certeau, The Practice of Everyday Life, trans. Steven Rendall (Berkeley: University of California Press, 1984 [1988]), 92.

${ }^{44}$ Ibid., 93.

${ }^{45}$ The novel's concern with material borders and spaces in its depiction of the characters' encounters is also worthy of analysis but beyond the scope of this article.

${ }^{46}$ Ahmed, Strange Encounters, 145.

${ }^{47}$ Robert Eaglestone, Ethical Criticism: Reading After Levinas (Edinburgh: Edinburgh University Press, 1997), 175; cited in Krishnan, 'Affect, Empathy, and Engagement', 221.

${ }^{48}$ Krishnan, 'Affect, Empathy, and Engagement', 220.

${ }^{49}$ Ibid., 228.

${ }^{50}$ Huggan, The Postcolonial Exotic, 39.

${ }^{51}$ James Procter, 'The Postcolonial Everyday', New Formations 58 (2006): 62-80, 66.

${ }^{52}$ Ibid.

${ }^{53}$ Procter, 'The Postcolonial Everyday', 67.

${ }^{54}$ Morey and Yaqin, Framing Muslims, 194.

${ }^{55}$ Examples of the visual as a positive means of asserting difference might include the Muslim 'veil' or beard, the Sikh turban or kara (bracelet) or kirpan (sword).

${ }^{56}$ Here my argument borrows from Brouillette's analysis of Derek Walcott's 'The Fortunate

Traveller', in Postcolonial Writers, 31-40, see especially 39.

${ }^{57}$ See Ahmed, Writing Muslims, Ch. 4, especially 141-43.

${ }^{58}$ See Kit De Waal, 'Don't Dip Your Pen in Someone Else's Blood: Writers and "the Other"', Irish Times (30 June 2018), https://www.irishtimes.com/culture/books/don-t-dip-your-pen-in-someoneelse-s-blood-writers-and-the-other-1.3533819 